УДК 378.147:808.5

DOI: $10.35619 /$ iiu.v1i10.166

Степанова Ольга

кандидат філологічних наук, доцент, доцент кафедри педагогіки і психології (дошкільної та корекційної) імені проф. Т. І. Поніманської Рівненського державного гуманітарного університету, м. Рівне, Україна ORCID: 0000-0001-6063-5110, e-mail: olgalingva55@gmail.com

\title{
РИТОРИЧНІ ВМІННЯ ЯК ОСНОВА ФОРМУВАННЯ КОМУНІКАТИВНО- МОВЛЕННСВОЇ КУЛЬТУРИ МАЙБУТНІХ ВИХОВАТЕЛІВ
}

Анотація. Матеріали статті розкривають одну з актуальних проблем підготовки майбутніх педагогів дошкільної освіти - розвиток комунікативно-мовленнєвої культури. У публікації репрезентовано аналіз категорії «комунікативно-мовленнєва культура» як лінгвістичного та соціопедагогічного феномену, виокремлено концептуальні основи і технологія їі розвитку в студентів під час навчання. У статті розкривається зміст формування комунікативно-мовленнєвої культури; окреслюється взаємозв'язок розвитку мовленнєвої та риторичної компетенції майбутнього педагога; висвітлюється організація викладання навчальної дисципліни «Культура мовлення та виразне читання» щодо спрямування студентів до засвоєння комунікативномовленнєвих умінь та навичок у межах предметно-спеціальної підготовки бакалаврів. Поряд із теоретичним матеріалом у статті подаються практичні поради, які допоможуть внести відповідні корективи в поведінку комунікантів. Відзначається, що в сучасних умовах спостерігається протиріччя: вимоги до сучасного учителя, вихователя, до його комунікативних якостей зростають, а реальний рівень випускників педагогічних професій залишається недостатнім. Значна увага приділяється аналізові шляхів розвитку комунікативно-мовленнєвої культури студентів вищих навчальних закладів. Важливим кроком вирішення цієї проблеми, на думку автора, є формування риторичних умінь у майбутніх педагогів закладів дошкільної освіти.

Ключові слова: комунікативна культура, мовленнєва культура, комунікативномовленнєва культура, риторичні уміння, майбутній педагог-вихователь закладів дошкільної освіти.

Постановка проблеми. Пріоритетним завданням підготовки сучасного педагога $€$ виховання культурної особистості. Стратегія освітнього процесу полягає в тому, щоб надати можливість його учасникам виявити свої здібності та творчий потенціал, оскільки сьогодні суспільству необхідні люди, які оригінально мислять і можуть швидко та нестандартно вирішувати проблеми. Сучасний фахівець повинен уміти контактувати, розуміти позицію вихованця, батьків, знаходити узгодженні рішення при обговоренні дискусійних питань тощо.

Від уміння ефективно спілкуватися залежать особистісні успіхи не тільки окремої людини, зокрема майбутнього освітянина, а і суспільства в цілому. Якість і результат людської життєдіяльності визначається культурою міжособистісних відносин. Основою загальної культури особистості, ії базовим компонентом є комунікативна культура, яка забезпечує життєве самовизначення людини, створює її внутрішній світ, життєві ідеали, цінності, систему заборон і самоконтролю, регулює процес адекватної реакції на оточуючу дійсність.

Відсутність необхідних навиків володіння комунікативною технікою певним учасником навчально-виховного процесу призводить до спотвореної передачі та 
прийому знань, ідей, думок i почуттів. 3 цієї причини розвиток мовленнєвокомунікативної культури, спеціальне навчання риторичним умінням $є$ вкрай важливим і на часі.

Мета статті полягає в розробці шляхів формування риторичних умінь і навичок майбутніх педагогів-вихователів ще на етапі їхньої підготовки у виші й обгрунтування можливостей курсу «Культура мовлення та виразне читання» в цьому процесі.

Аналіз останніх досліджень і публікацій. Комунікативно-риторичні вміння були в центрі уваги ще античних риторів. Вони називали їх «ідеями» і пов'язували з особою мовця, який, на думку Діонісія, повинен бути схожим на Протея, що міняв свою подобу залежно від умов. Створюється така подоба шляхом комбінацій «ідей», тобто найменших елементів стилю (Бацевич, 2004).

Сучасні вчені у своїх працях висвітлюють проблеми комунікативно-мовленнєвої культури (Б. Антоненко-Давидович, В. Берков, Г. Волкотруб, О. Горбул, О. Кубрак, О. Сербенська, Ф. Хміль, Т. Чмут, С. Шевчук та ін.). Дослідженням питань виховання риторичних умінь займалися такі мовознавці та методисти, як: Н. Бабич, О. Біляєв, М. Вашуленко, Б. Головін, С. Єрмоленко, М. Жовтобрюх, С. Караман, А. Коваль, Т. Ладиженська, М. Пентилюк, М. Стельмахович, Й. Стернін та ін.

Комунікативно-мовленнєву культуру людина удосконалює все своє життя в різноманітних ситуаціях, 3 різними людьми, перебуваючи в різних обставинах (Бацевич, 2004).

У процесі підготовки майбутніх педагогів-вихователів однією 3 найважливіших $\epsilon$ проблема формування в них комунікативно-мовленнєвої культури. Загалом комунікативно-мовленнєва культура особистості є проявом індивідуальної рефлексії, інтеріорізованим досвідом загальнолюдської культури, що й зумовлює своєрідність кожної особистості» (Корніяка, 1995).

О. Корніяка відзначає, що «...в сучасній літературі комунікативно-мовленнєва культура розглядається як морально зорієнтований спосіб комунікації, що забезпечує афективно-інформаційний обмін між людьми, опосередковує їхню взаємодію та взаємовплив, уможливлює міжособистісне сприймання та взаєморозуміння; це більшменш довершена готовність, спроможність особистості до спілкування 3 оточенням» (1995).

Т. Чмут розглядає зміст поняття «комунікативно-мовленнєва культура» як «...специфічний прояв соціальної культури, що характеризується «людським виміром» суспільних і міжсуб'єктних відносин і переслідує мету взаємозбагачення індивідів засобами інформаційного обміну, взаємотрансляції знань, розповсюдження позитивного життєвого досвіду спільного існування» (2002).

Л. Орбан-Лембрик тлумачить комунікативно-мовленнєву культуру як:

- здатність до узгодження й зіставлення своїх дій 3 іншими, прийняття й сприйнятливості іншого, підбору та пред'явлення аргументів, висування альтернативних пояснень, обговоренню проблеми, розуміння думок інших i, на основі цього, до регулювання відносин для створення спільності комунікантів у досягненні єдиної мети діяльності;

- потреба в іншому, в розширенні меж комунікацій, зіставленні поглядів, уміння стати на позицію контрагента;

- готовність до гнучкої тактовної взаємодії з іншими, до рефлексивної діяльності, до проектування комунікативних умінь і застосуванню їх у новій ситуації.

Учена переконливо довела, що комунікативну культуру можна представити як складову професійної культури, яка характеризується особистісною та професійною цінністю, спрямованістю на іншого суб'єкта комунікативного процесу (2010).

Як слушно, на наш погляд, стверджують більшість сучасних дослідників, поняття «комунікативно-мовленнєва культура» $\epsilon$ досить складним за структурою й інтегративним за природою. В основі комунікативно-мовленнєвої культури лежить 
культура мислення як специфічна форма пізнавальної діяльності, спрямована на пізнання дійсності, а також культура мовлення (Стернін, 2000).

Виклад основного матеріалу дослідження. Комунікативна культура освітянина основана на мовленнєвій, тому, на нашу думку, не варто розмежовувати визначення «комунікативна» i «мовленнєва». Мовлення педагога визначає як потенціал усієї системи освіти, так і розвиток особистості вихованця. Зміст його професійної діяльності ставить до нього низку специфічних вимог, що сприяють розвиткові певних особистісних якостей як професійно значущих, необхідних та обов'язкових.

Мовлення вихователя - не тільки головне знаряддя професійної діяльності, але й зразок для наслідування. Професія учителя, вихователя наділена підвищеною мовленнєвою відповідальністю та вимагає бездоганного оволодіння культурою мовленнєвого спілкування.

Н. Бабич справедливо зауважує, що «в основі педагогічної діяльності лежить комунікативна, за допомогою якої учитель передає знання, керує пізнавальнопрактичною діяльністю дітей, регулює їхні взаємовідносини (1990).

Отже, кожен освітянин повинен уміти здійснювати вибір моделі своєї поведінки не тільки в залежності від оточуючих його людей, але й від усвідомлення того, що для цього оточення така поведінка $є$ зразком для наслідування. Саме в цьому, на наш погляд, полягає сутність професійної комунікативної культури педагога.

Практика свідчить, що сучасні молоді вихователі далеко не завжди мають відповідні мовленнєві навики. Невміння враховувати мовленнєву ситуацію, використання стилістично недоречної лексики, мовленнєва агресія - далеко не повний перелік мовленнєвої поведінки сьогоднішніх педагогів-початківців. Спостерігається протиріччя - вимоги до педагогів, їхніх комунікативних якостей зростають, а реальний рівень мовленнєвої підготовки випускників педагогічних факультетів залишається недостатнім.

Існує низка причин, що сприяють розвитку цього протиріччя, основними з яких є: а) невиправдане вживання запозичень, розмовної і жаргонної лексики; б) відсутність розуміння важливості збереження літературної мови в сучасної молоді; в) зниження інтересу до читання класичної літератури; г) засилля низькопробних зразків, їхня пропаганда в ЗМІ тощо. Усе це призводить до зникнення традиційних основ національного мовленнєвого етикету i, як результат, - до падіння рівня мовленнєвої культури суспільства.

Водночас, комунікативна культура педагога в основному формується стихійно, спонтанно, ніби $є$ другорядним завданням його професійної підготовки. Це можна пояснити недостатнім рівнем науково-методичного забезпечення формування комунікативної культури майбутніх педагогів-вихователів. Тож, освіта «відстає від сучасних вимог до комунікативної культури, і до культури взагалі» (Стернін, 2000).

Вирішенню цієї проблеми сприятиме збільшення в навчальних планах підготовки бакалаврів за спеціальністю 012 «Дошкільна освіта» кількості дисциплін за вибором риторичної спрямованості або активне використання впливу комунікативномовленнєвого підходу при викладанні інших предметів гуманітарного циклу, зокрема, педагогіки, психології, історії України, філософії тощо. Певні кроки для усунення названих протиріч ми вбачаємо у формуванні в майбутніх педагогів-вихователів риторичних умінь. Для цього необхідно окреслити основні завдання мовленнєвої підготовки студентів; змоделювати іiі технології та розробити педагогічні умови іiі ефективності.

Тому, дуже важливо, що до стандартів освіти для майбутніх вихователів дошкільних закладів уведено навчальну дисципліну «Культура мовлення та виразне читання». У професійно-педагогічній діяльності мовленнєва культура перетворюється на основний, професійно значущий фактор; стає інструментом впливу, а всі ії функції та завдання ускладнюються, оскільки із загальнолюдських аспектів переростають у професійно-творчі. 
Незважаючи на те, що через недостатню кількість відведених годин, цей курс не вирішує всіх зазначених вище завдань, проте спрямований на оволодіння майбутніми спеціалістами риторичними знаннями, правилами і нормами спілкування, вимогами до мовленнєвої поведінки в різних ситуаціях, формування риторичних умінь, усвідомлення специфіки професійного педагогічного мовленнєвого спілкування, здатності вирішувати комунікативні та мовленнєві завдання в конкретних ситуаціях, оволодіння досвідом продукування й аналізу професійно значимих мовленнєвих жанрів, розвиток творчо активної мовленнєвої особистості, пізнання суті риторичного ідеалу як основи гармонізації педагогічного спілкування.

Риторичні уміння - це такі, які сприяють розвитку/формуванню свідомого ефективного мовленнєвого впливу на людину під час міжособистісного, групового та колективного публічного спілкування (Мацько, 2006).

На нашу думку, професійно орієнтовану мовленнєву діяльність майбутніх педагогів, формування їхньої комунікативно-мовленнєвої підготовки доцільно здійснювати на основі загальної та часткової риторики.

Навчання риторики передбачає формування риторичних умінь: засвоєння базових жанрово-стилістичних навиків, свідомих способів виконання риторичних дій (находження або створення матеріалу мовлення чи тексту, розташування або композиція матеріалу, словесні вирази або дикція, пам'ять, запам'ятовування, виконання (вимовляння) під час міжособистісного, групового i колективного публічного спілкування (Чмут, 2002).

Формування риторичних умінь повинно проходити в декілька етапів: а) представлення мовленнєвої або поведінкової моделі; б) імітація зразка; в) відкладене відтворення; г) тверде запам'ятовування; д) вільне використання в нових умовах. 3 метою засвоєння певного навику доцільно дотримуватися такої послідовності вправ: а) пропедевтичні; б) наочні; в) закріплюючі; г) повторювальні; д) узагальнювальні; є) творчі. Важливо добирати такі завдання, які в процесі оволодіння матеріалом спонукають студентів до активної мислительної та мовленнєвої діяльності. У якості завдань здобувачам першого ступеня вищої освіти пропонується аналіз тексту-зразку (відзначимо, що усі вони несуть культурологічну функцію і сприяють розширенню світогляду студенів, наприклад, твори Григорія Сковороди, Івана Франка, Михайла Драгоманова, Івана Вихованця, Свгена Гуцала та ін.), тексти, які складені сокурсниками тощо. Творчі завдання, спрямовані на утворення власного висловлювання, завжди викликають живий інтерес аудиторії.

Увага студентів акцентується на значущості традиційних основ національного мовленнєвого етикету, оволодіння мовними, етичними і комунікативними нормами. Риторичний аналіз тексту допомагає майбутнім педагогам досить успішно продукувати власні висловлювання. У процесі навчання закріплюються знання про навчально-мовленнєві ситуації, іiі базових складових, виконуються не тільки аналітичні, але і творчі завдання. Продукування й аналіз навчально-мовленнєвих ситуацій, рольові ігри, дискусії дозволяють майбутнім вихователям закладів дошкільної освіти заглибитися в зміст педагогічної професії, відпрацювати комунікативно-мовленнєві вміння та навички, що лежать в основі свідомого ефективного впливу. Для засвоєння риторичних умінь при вивченні дисципліни «Культура мовлення та виразне читання» передбачено традиційні форми контролю: 1) вихідний контроль. Метою $є$ виявити вихідний рівень комунікативно-мовленнєвих умінь студентів для визначення можливостей удосконалення риторичної підготовки 3 урахуванням базових знань і навичок. На цьому етапі студентам пропонується текст, що містить інформацію про важливість риторики та мовленнєвої культури, пропонується висловити свою думку щодо позиції автора тексту, аргументувати ії; 2) тимчасовий контроль. Мета полягає в тому, щоб перевірити уміння продукувати текст (складання риторичного ескізу мовлення), представляти його в аудиторії 3 урахуванням комунікативного співробітництва і законів сучасної загальної риторики; 
уміння використовувати методи захоплення та утримання уваги аудиторії, оволодіння невербальними засобами спілкування. Студентам пропонується підготувати переконливі висловлювання, вибравши одну з тем: «Я повинен бути жорстоким, щоб бути добрим?», «Чи легко бути сьогодні молодим?», «Навчатися - це модно?», «Матеріальні блага - це основа життя?», «Бути вихователем - це престижно?». Підготовлені висловлення презентуються усно в аудиторії, а колективно аналізуються та оцінюються. 3) підсумковий контроль. Мета - виявити рівень сформованості теоретичних знань і практичних умінь студентів з вивчених тем за вибором, приміром, «Риторика для майбутнього педагога-вихователя». Окрім тестування, студенти здійснюють і риторичний аналіз текстів і продукують навчально-мовленнєві ситуації на задані теми.

Комунікативно-мовленнєва культура визначає успішність педагога-вихователя, $є$ основою його професійної майстерності. Сформованість комунікативної культури можна визначити за такими групами критеріїв: 1) культура спілкування, товариськість; 2) культура мовлення; 3) риторичні уміння; 4) риторичне/комунікативне мислення; 5) ціннісні орієнтації; 6) дозвільні інтереси.

Висновки і перспективи подальших розвідок. Отже, проаналізовані протиріччя частково вирішуються при вивченні дисципліни «Культура мовлення та виразне читання», а також в межах предметно-спеціальної підготовки бакалаврів.

Вихователь - професія підвищеної мовленнєвої відповідальності, особливо в закладах дошкільної освіти, де закладаються основи становлення особистості, тому риторична підготовка майбутнього педагога-вихователя, формування його комунікативно-мовленнєвої культури - одне 3 найважливіших завдань сучасної педагогічної освіти. Тільки цілеспрямована систематична робота над риторичними вміннями майбутніх педагогів забезпечить у них формування комунікативномовленнєвої культури.

\section{СПИСОК ВИКОРИСТАНИХ ДЖЕРЕЛ}

Бацевич, Ф. (2004). Основи комунікативної лінгвістики. Київ : Академія. 342 с.

Корніяка, О. (1995). Мистецттво тречності: Чи вміємо ми себе поводити? Київ : Либідь. 95 с.

Чмут, Т. (2002). Шляхи розвитку культури спілкування студентів вищих навчальних закладів: навчальний посібник. Київ : Основа. 380 с.

Орбан-Лембрик, Л. (2010). Психологія професійної комунікаиії: навч. посіб. Чернівці : Книги - XXI. 528 с.

Стернин, И. (2000). Модели описания коммуникативного поведения. Воронеж : Истоки. 27 с.

Бабич, Н. (1990). Основи культури мовлення. Львів : Світ. 232 с.

Мацько, Л., Мацько, О. (2006). Риторика : навч. посіб. Київ : Вища школа. 311 с.

\section{REFERENCES}

Batsevych, F. (2004). Osnovy komunikatyvnoi linhvistyky [Basics of Communicative Linguistics]. Kyiv : Akademiia. 342 s. (in Ukrainian)

Korniiaka, O. (1995). Mystetstvo grechnosti: Chy vmiiemo my sebe povodyty? [The Art of Politeness: Do We Know How to Behave?]. Kyiv : Lybid, 95 s. (in Ukrainian)

Chmut, T. (2002). Shliakhy rozvytku kultury spilkuvannia studentiv vyshchykh navchalnykh zakladiv: navchalnyi posibnyk [The Ways to Develop the Culture of Communication among Students of Higher Education Institutions]. Kyiv : Osnova. 380 s. (in Ukrainian)

Orban-Lembryk, L. (2010). Psykholohiia profesiinoi komunikatsii: navch. posib. [The Psychology of Professional Communication]. Chernivtsi : Knyhy - XXI. 528 s. (in Ukrainian)

Sternyn, I. (2000). Modeli opisaniya kommunikativnogo povedeniya [Patterns of Description of Communicative Behavior]. Voronezh : Istoki. 27 s. (in Russian) 
Babych, N. (1990). Osnovy kultury movlennia [Basics of Speech Culture]. Lviv : Svit. 232 s. (in Ukrainian)

Matsko, L., Matsko, O. (2006). Rytoryka : navch. posib. [Rhetoric]. Kyiv : Vyshcha shkola. 311 s. (in Ukrainian)

\title{
RHETORICAL SKILLS AS A BASIS FOR THE FORMATION OF THE COMMUNICATIVE-SPEECH CULTURE IN FUTURE PRESCHOOL TEACHERS
}

\author{
Olha Stepanova \\ Candidate of Philological Sciences, Associate Professor, \\ Associate Professor at the Department of Pedagogy \\ and Psychology (Preschool and Correctional) \\ named after Professor T.Ponimanska, \\ Rivne State University for the Humanities, \\ Rivne, Ukraine \\ ORCID: 0000-0001-6063-5110, \\ e-mail: olgalingva55@gmail.com
}

\begin{abstract}
The article deals with one of the actual issues of training in future teachers of preschool education - development of communicative-speech culture. The publication represents the analysis of the category "communicative-speech culture" as a linguistic and socio-pedagogical phenomenon, revealed conceptual foundations and technology of its development in students during the studies. The article reveals the content of the communicative-speech culture. The relationship of the development of speech and rhetorical competence of the future teacher is determined. Organization of teaching and expressive reading of the educational discipline «culture of speech» on the direction of students to learn the communicative-speech skills and skills within the subject-special training of bachelors is highlighted.

Along with the theoretical material, the article provides practical tips that will help to make appropriate adjustments to the behavior of communicators. It is noted that in modern conditions there is a contradiction: requirements to the modern teacher, educator, it communication qualities grow, and the real level of graduates of pedagogical professions remains insufficient. A great attention is paid to the analytical ways of development of communicative-speech culture of students of higher educational establishments. An important step in solving this problem, according to the author's position, is the formation of rhetorical skills in future teachers of preschool education institutions.

Important component of professional competence of future the teacher of preschool education is rhetorical culture. It includes language art skills, the ability to speak clearly, meaningful, expressive, adhere to the requirements of general culture and culture of speech communication. Teaching of rhetoric develops a set of personal values of the person: culture of language, logical thinking, skill, ability to control the behavior of the audience. Future preschool teacher training should understand the nature of such concepts and phenomena as diction, culture of language. Thus, it is necessary to work on adjusting deviations from literary norm.
\end{abstract}

Keywords: communicative culture, speech culture, communicative-speech culture, rhetorical skills, future teacher of preschool educational establishments.

Стаття надійшла до редакиії 04.10.2019p. 